\title{
Porous concrete basic property criteria as rigid pavement base layer in indonesia
}

\author{
FriskyRidwan Aldila Melania Care ${ }^{1}$, BambangSugeng Subagio ${ }^{2}$, and Harmein Rahman ${ }^{3}$ \\ ${ }^{1}$ Transport Engineering Research Group, Faculty of Civil Engineering and Environment, Bandung Institute of Technology, \\ Jalan Ganeca 10 Bandung, Indonesia \\ ${ }^{2}$ Transport Engineering Research Group, Faculty of Civil Engineering and Environment, Bandung Institute of Technology, \\ Jalan Ganeca 10 Bandung, Indonesia \\ ${ }^{3}$ Transport Engineering Research Group, Faculty of Civil Engineering and Environment, Bandung Institute of Technology, \\ Jalan Ganeca 10 Bandung, Indonesia
}

\begin{abstract}
Base layer with grained material tend to occur in saturated condition at the moment of rainfall or after rainfall. In that condition, the present of traffic might also create movement below the foundation layer and reduce its bearing capacity. Nevertheless, the foundation material that contain large fine creates base layer with low permeability and slow water movement. This paper presented the procedure and result of laboratory experimental study to obtain basic property criteria for rigid pavement base layer.The porous concrete mixture was successfully designed and surpassed the minimum requirements required by Directorate General of Highways [11] [12]. It was found that there was very strong correlation between void content and permeability which created fine likelihood to use void content to represent porous concrete permeability behavior. High void content with good connection resulting weaker aggregate interlocking inside the mixture so that permeability rose whereas compressive strength fell. Solid fresh density and more filled by cement paste created a smaller void that would reduce permeability and improve compressive strength. Strong correlation between fresh density towards void content and permeability opened potency to use the fresh density as a reference to set the desired porous concrete void content on the field.
\end{abstract}

Keywords:Porous Concrete, Base Layer, Rigid Pavement, Fresh Density, Compressive Strength, Void Content, Permeability.

\section{Introduction}

In this couple of year, concrete technology has been developed significantly. One of the latest product is a modern concrete mix-design called porous concrete. Porous concrete, sometimes referred to as no-fines, gapgraded, permeable, or enhanced porosity concrete, is an innovative approach for controlling, managing, and treating stormwater runoff. When used in pavement applications, pervious concrete can effectively capture and store stormwater runoff, thereby allowing the runoff to percolate into the ground and recharge groundwater supplies. (FHWA [13]).

In Indonesia, most of rigid pavement structures generally use grained material such as class A or Class B aggregate as base layer. The foundation of rigid pavement might also serve as drainage layer to prevent pumping and intrusion at joint locations, cracks dan the edge of plate (Center of Transportation Infrastructure Research and Development [9]). However, base layer with grained material tend to occur in saturated condition at the moment of rainfall or after rainfall. In that condition, the present of traffic also create movement below the foundation layer and reduce its bearing capacity. In several cases, base layer is employed to grant a uniform support for rigid pavement structure. The increasing of traffic load will aim to the use of denser, more robust and anti-erosion base material as well. The foundation material that contain large fine creates base layer with low permeability and slow water movement. The combination of trapped infiltration water and repeated traffic loading will generate void between base layer surface and surface layer base (erosion). The majority of infiltrated water that accumulated inside the void comes from pavement surface by infiltration through cracks, joints and gaps alongside the edge of pavement. Erosion phenomenon could lead to the loss of foundation support, pavement premature distress and short-term service life issue (Kozeliski [15]).

Survey results related to rigid pavement distress had been collected from several toll roads and highways in Indonesia. The amount of pumping, faulting and longitudinal cracking distress were very plentiful, especially in highway. These types of distress usually happened due to loss of foundation support, poor drainage and erosion problem in base layer (Huang [14]). Hence, a base layer with drainage type like porous concrete was required to tackle those problems. Researches have shown that a permeable base layer must meet three requirements. First, it must have enough permeability to quickly free itself from any water that has entered and then is trapped in the pavement structure. Secondly, it must have sufficient strength to

\footnotetext{
Corresponding author:friskyramc@gmail.com
} 
serve as a pavement construction platform. Finally, the design should meet the strength requirements to carry the traffic loads of the pavement structure (Zheng [24]). In addition, the porous concrete mixture should fulfill the base layer criteria which was required in Indonesian Guidance, Manual or Specification as well (Table 1).

Table 1.Rigid pavement base layer criteria (Center of Transportation Infrastructure Research and Development [9]; Directorate General of Highways[11] [12]).

\begin{tabular}{|c|c|c|c|}
\hline $\begin{array}{c}\text { Base } \\
\text { Layer } \\
\text { Type }\end{array}$ & $\begin{array}{c}\text { Minimum } \\
\text { f'c value } \\
\text { 7 days } \\
\text { (MPa) }\end{array}$ & $\begin{array}{c}\text { Minimum } \\
\text { f'c value } \\
\mathbf{2 8} \text { days } \\
\text { (MPa) }\end{array}$ & $\begin{array}{c}\text { Minimum } \\
\text { k value } \\
\text { (cm/sec) }\end{array}$ \\
\hline $\begin{array}{c}\text { Cement } \\
\text { Treated } \\
\text { Base }\end{array}$ & $4.5-5.5$ & - & - \\
\hline $\begin{array}{c}\text { Lean } \\
\text { Concrete }\end{array}$ & $5.6-7.7$ & $8.0-11.0$ & - \\
\hline $\begin{array}{c}\text { Aggregate } \\
\text { Class A }\end{array}$ & - & - & 0.1 \\
\hline
\end{tabular}

\section{Research Methodology}

The laboratory study of porous concrete basic property criteria as rigid pavement base layer consists of following three main steps: (a) porous concrete mixdesign proportion; (b) measurement of basic design parameters based on fresh density, compressive strength, void content and permeability; (c) Statistical correlation test between the parameters. These three steps are described in detail in the following sub-sections. All of the material properties are tested based on ASTM. The minimum criteria for mix-design will be attained by varying the aggregate cement ratio, water cement ratio and aggregate size value along with sand addition, flyash replacement and chemical additive addition such as HRWR, VMA and retarder.

\subsection{Mix Design Proportion}

Porous concrete mixtures were designed using ACI Committee 522 standard and some references from Meininger's [18] experimental test result. These mixtures will consists of uniform graded coarse aggregate, portland cement type I, water, sand, fly-ash class F, HRWR, VMA and retarder. The chemical additive dosage was used based on reference from Anderson [3]. External vibration combined with iron stick stabbing 25 times was used as compaction method. Polyethylene bag curing method was conducted to gain optimum compressive strength (Yusak [23]). Compressive strength specimens test were cast into cylinders with diameter 6" and length 12" (ASTM C-39 [5]), whereas void content and permeability specimens test were cast into cylinders with diameter 5" and length 5.24" (ASTM D-5084 [8]). Table 2 and Table 3 show the overall of porous concrete mix-design proportion in this research.
Table 2.Porous concrete mix-design proportion for preliminary test $\left(1 \mathrm{~m}^{3}\right.$ concrete).

\begin{tabular}{|c|c|c|c|c|c|}
\hline w/c & $\mathbf{A} / \mathbf{C}$ & $\begin{array}{c}\text { Cement } \\
(\mathbf{k g})\end{array}$ & $\begin{array}{c}\text { Water } \\
(\mathbf{k g})\end{array}$ & $\begin{array}{c}\text { Aggregate } \\
\mathbf{( k g )}\end{array}$ & $\begin{array}{c}\text { Retarder } \\
(\mathbf{k g})\end{array}$ \\
\hline$* 0.27$ & 4.0 & 338.2 & 91.3 & 1367.0 & 2.0 \\
\hline 0.27 & 4.0 & 338.2 & 91.3 & 1367.0 & 2.0 \\
\hline$* 0.30$ & 4.0 & 345.1 & 103.5 & 1367.0 & 2.1 \\
\hline 0.30 & 4.0 & 345.1 & 103.5 & 1367.0 & 2.1 \\
\hline$* 0.33$ & 4.0 & 343.9 & 113.5 & 1367.0 & 2.1 \\
\hline 0.33 & 4.0 & 343.9 & 113.5 & 1367.0 & 2.1 \\
\hline$* 0.27$ & 6.0 & 228.4 & 61.7 & 1367.0 & 1.4 \\
\hline 0.27 & 6.0 & 228.4 & 61.7 & 1367.0 & 1.4 \\
\hline$* 0.30$ & 6.0 & 228.1 & 68.4 & 1367.0 & 1.4 \\
\hline 0.30 & 6.0 & 228.1 & 68.4 & 1367.0 & 1.4 \\
\hline$* 0.33$ & 6.0 & 227.9 & 75.2 & 1367.0 & 1.4 \\
\hline 0.33 & 6.0 & 227.9 & 75.2 & 1367.0 & 1.4 \\
\hline$*$ curing at 7-days $;$ curing at 28-days ; aggregate size $12.7 \mathrm{~mm}$
\end{tabular}

Table 3.Porous concrete mix-design proportion $\left(1 \mathrm{~m}^{3}\right.$ concrete)

\begin{tabular}{|c|c|c|c|c|c|c|}
\hline $\begin{array}{c}\text { Cement } \\
(\mathbf{k g})\end{array}$ & $\begin{array}{c}\text { Water } \\
(\mathbf{k g})\end{array}$ & $\begin{array}{c}\text { Aggregate } \\
(\mathbf{k g})\end{array}$ & $\begin{array}{c}\text { Sand } \\
\mathbf{( k g})\end{array}$ & $\begin{array}{c}\text { Fly-ash } \\
(\mathbf{k g})\end{array}$ & $\begin{array}{c}\text { HRWR } \\
(\mathbf{m L})\end{array}$ & $\begin{array}{c}\text { Retarder } \\
\mathbf{8} \text { VMA } \\
(\mathbf{m L})\end{array}$ \\
\hline$* 342.8$ & 99.4 & 1367.0 & - & - & 0.7 & 2.1 \\
\hline 342.8 & 99.4 & 1367.0 & - & - & 0.7 & 2.1 \\
\hline$* 342.8$ & 99.4 & 1367.0 & - & - & 0.7 & 2.1 \\
\hline 342.8 & 99.4 & 1367.0 & - & - & 0.7 & 2.1 \\
\hline$* 342.8$ & 99.4 & 1367.0 & - & - & 0.7 & 2.1 \\
\hline 342.8 & 99.4 & 1367.0 & - & - & 0.7 & 2.1 \\
\hline$* 328.7$ & 93.9 & 1307.6 & 66.5 & - & 0.6 & 2.1 \\
\hline 328.7 & 93.9 & 1307.6 & 66.5 & - & 0.6 & 2.1 \\
\hline$* 312.1$ & 89.1 & 1248.1 & 126.9 & - & 0.6 & 2.0 \\
\hline 312.1 & 89.1 & 1248.1 & 126.9 & - & 0.6 & 2.0 \\
\hline$* 341.2$ & 96.9 & 1367.0 & - & 37.9 & 0.7 & 2.4 \\
\hline 341.2 & 96.9 & 1367.0 & - & 37.9 & 0.7 & 2.4 \\
\hline
\end{tabular}

*curing at 7-days ; curing at 28-days ; aggregate size $9.5 \mathrm{~mm}$; aggregate size $12.7 \mathrm{~mm}$; aggregate size $19.0 \mathrm{~mm}$

\subsection{Measurement of Basic Design Parameter}

Four basic parameters were applied to represent the required criteria for pavement base layer: (1) fresh density; (2) compressive strength; (3) void content; (4) permeability. All of the explanation about the variable in the equations are attached in Nomenclature along with their units.

Fresh density describes the density of freshly mixed pervious concrete. The test was conducted in accordance with ASTM C-1688 [6] and calculated using formula: 


$$
\begin{array}{r}
D=\frac{M_{c}-M_{m}}{V_{m}} \\
T=\frac{M_{S}}{V_{S}}
\end{array}
$$

where:

$\mathrm{D}=$ density of concrete $\left(\mathrm{kg} / \mathrm{m}^{3}\right)$

$\mathrm{M}_{\mathrm{c}}=$ mass of the measure filled with concrete

$(\mathrm{kg})$

$\mathrm{M}_{\mathrm{m}}=$ mass of the measure $(\mathrm{kg})$

$\mathrm{V}_{\mathrm{m}}=$ volume of the measure $\left(\mathrm{m}^{3}\right)$

$\mathrm{T}=$ theoretical density of concrete computed on an airfree basis $\left(\mathrm{kg} / \mathrm{m}^{3}\right)$

$\mathrm{M}_{\mathrm{s}}=$ total mass of all materials batched $(\mathrm{kg})$

$\mathrm{V}_{\mathrm{s}}=$ sum of the absolute volumes of the component ingredients in the batch $\left(\mathrm{m}^{3}\right)$

Compressive Strength $\left(\mathrm{f}^{\prime}{ }_{\mathrm{c}}\right)$ describes the typical concrete ability to receive compressive force per unit area. The compressive strength test was conducted in accordance with ASTM C-39 [5] and calculated using formula:

$$
f^{\prime} c=\frac{F}{A}
$$

where:
$\mathrm{f}^{\prime}{ }_{\mathrm{c}}=$
compressive strength ( $\mathrm{MPa})$
$\mathrm{F}=$
maximum compressive force $(\mathrm{N})$
$\mathrm{A}=$
cross-sectional area of the specimen $\left(\mathrm{m}^{2}\right)$

Void content $\left(\mathrm{V}_{\mathrm{r}}\right)$ describes the total open space within the porous concrete. It is a comparison of the volume of voids, to the total volume of cement paste and aggregate. The void content test was conducted in accordance with ASTM C-1688 [6] and ASTM C-1754 [7] and calculated using formula:

$$
\begin{gathered}
U=\frac{T-D}{T} x 100 \\
\mathrm{~V}_{r}=\left[1-\left(\frac{M_{w}-M_{d}}{\rho_{w} \times V o l}\right)\right]
\end{gathered}
$$

where:

$\begin{array}{lll}\mathrm{U}= & \begin{array}{l}\text { percentage of voids in the fresh porous } \\ \text { concrete, includingentrained and entrapped } \\ \text { air voids in the cement paste } \\ \text { theoretical density of concrete computed } \\ \text { on an airfree basis }\left(\mathrm{kg} / \mathrm{m}^{3}\right)\end{array} \\ \mathrm{T} & =\begin{array}{l}\text { density of concrete }\left(\mathrm{kg} / \mathrm{m}^{3}\right) \\ \mathrm{D}\end{array} \\ \mathrm{V}_{\mathrm{r}}= & \text { void content }(\%) \\ \mathrm{M}_{\mathrm{w}}= & \text { specimen mass in water }(\mathrm{kg}) \\ \mathrm{M}_{\mathrm{d}}= & \text { dry specimen mass }(\mathrm{kg}) \\ P_{\mathrm{w}}= & \text { density of water }\left(\mathrm{kg} / \mathrm{m}^{3}\right) \\ \mathrm{V}_{\mathrm{ol}}= & \text { volume of specimen }\left(\mathrm{m}^{3}\right)\end{array}$

Permeability describes the easiness of concrete to be penetrated or passed by liquid or gas. Normally, the material permeability is indicated by its hydraulic conductivity or permeability value. Darcy's Law defines hydraulic conductivity as the ratio of fluid average velocity that passing through a transverse area against applied hydraulic gradient. The test was conducted using modified falling head permeameter apparatus which developed by McCain [17]. Montes and Haselbach [19] showed that under these head values laminar flow conditions are expected to exist in pervious concrete pavement and Darcy's law can be used to determine the hydraulic conductivity. The permeability test was conducted in accordance with ASTM D-5084 [8] and calculated using formula:

$$
\mathrm{k}=\frac{a \cdot L}{A \cdot t} \ln \left(\frac{h_{1}}{h_{2}}\right)
$$

where :

$\begin{array}{lll}\mathrm{k} & = & \text { permeability coefficient }(\mathrm{m} / \mathrm{s}) \\ \mathrm{a} & = & \text { cross-sectional area of the standpipe }\left(\mathrm{m}^{2}\right) \\ \mathrm{L} & = & \text { length of the specimen }(\mathrm{m}) \\ \mathrm{A} & = & \text { cross-sectional area of the specimen }\left(\mathrm{m}^{2}\right) \\ \mathrm{t} & = & \text { time for water to drop from } \mathrm{h}_{1} \text { to } \mathrm{h}_{2}(\mathrm{~s}) \\ \mathrm{h}_{1} & = & \text { initial water level }(\mathrm{m}) \\ \mathrm{h}_{2} & = & \text { final water level }(\mathrm{m})\end{array}$

\subsection{Statistical Correlation Test}

The correlation between the basic design parameters was described using simple correlation test. This test is a statistical technique which is used to measure the relationship level between 2 variables and the shape of their relationship. The relationship level is stated in number wherein bigger number shows stronger relationship (Table 4). The simple correlation test was computed utilizing formula:

$$
R^{2}=\frac{\sum X Y}{\sqrt{\sum X^{2} \sum Y^{2}}}
$$

where:

$\begin{array}{lll}\mathrm{R}^{2} & = & \text { simple correlation coefficient } \\ \mathrm{X} & = & \text { independent variable } \\ \mathrm{Y} & = & \text { dependent variable }\end{array}$

Table 4.Guidance of correlation coefficient interpretation.

\begin{tabular}{|c|c|}
\hline $\begin{array}{c}\text { Value of Correlation } \\
\text { Coefficient }\end{array}$ & $\begin{array}{c}\text { Relationship } \\
\text { Interpretation }\end{array}$ \\
\hline $0,000-0,199$ & Very Weak \\
\hline $0,200-0,399$ & Weak \\
\hline $0,400-0,599$ & Moderate \\
\hline $0,600-0,799$ & Strong \\
\hline $0,800-1,000$ & Very Strong \\
\hline
\end{tabular}

\section{Test Results and Discussion}

This section covers the result of basic design parameter and correlation of basic parameter. Several discussions were attached as well to illustrate the laboratory test result.

\subsection{Statistical Correlation Test}

Preliminary test was conducted to obtain the optimum compressive strength and void content by varying water cement ratio and aggregate cement ratio. The preliminary test results are showed on Figure 1 to Figure 3. 
As can be seen from Figure 1 mix-proportion with A/C $=4.0$ had a higher compressive strength value compared to $\mathrm{A} / \mathrm{C}=6.0$ at the age of 7-days and 28-days. In addition, the porous concrete mixture also had an optimum compressive strength value at specific water cement ratio wherein 0.30 was showed as an optimum value in this case. Both of these conditions nearly close to the results which were gained by Meininger [18] and Amde [2].

FromFigure $\mathbf{2}$ and Figure $\mathbf{3}$, therewere a dramaticdecreasefrom the void content and permeability value due to the raise of water cement ratio and the subtraction of aggregatecement ratio McCain [17]. This condition alsoshowed a potency of compressive strengthenhancement by reducing the aggregatecement ratio value. Therefore, $\mathrm{w} / \mathrm{c}=0.30$ and $\mathrm{A} / \mathrm{C}=4.0$ wouldbechosen as reference to create the nextspecimen composition usingaggregate variation and additive inclusion. The following compressive strength test results are presented on Figure 4 and Figure 5.

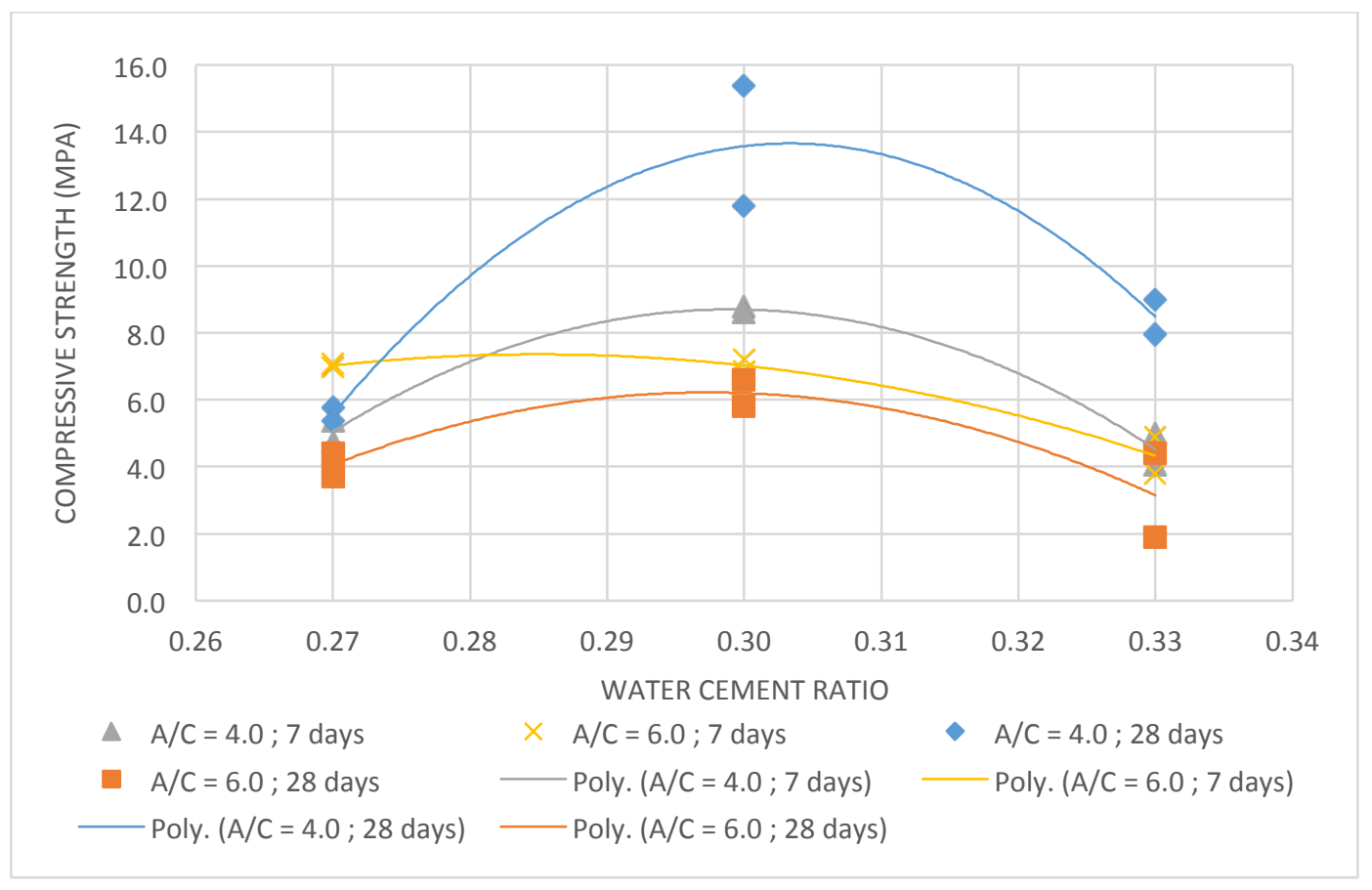

void content range: $28 \%-40 \%$

permeability coefficient range: $2.5 \mathrm{~cm} / \mathrm{sec}-4.7 \mathrm{~cm} / \mathrm{sec}$

Figure1.Relationship between water cement ratio and compressive strength.

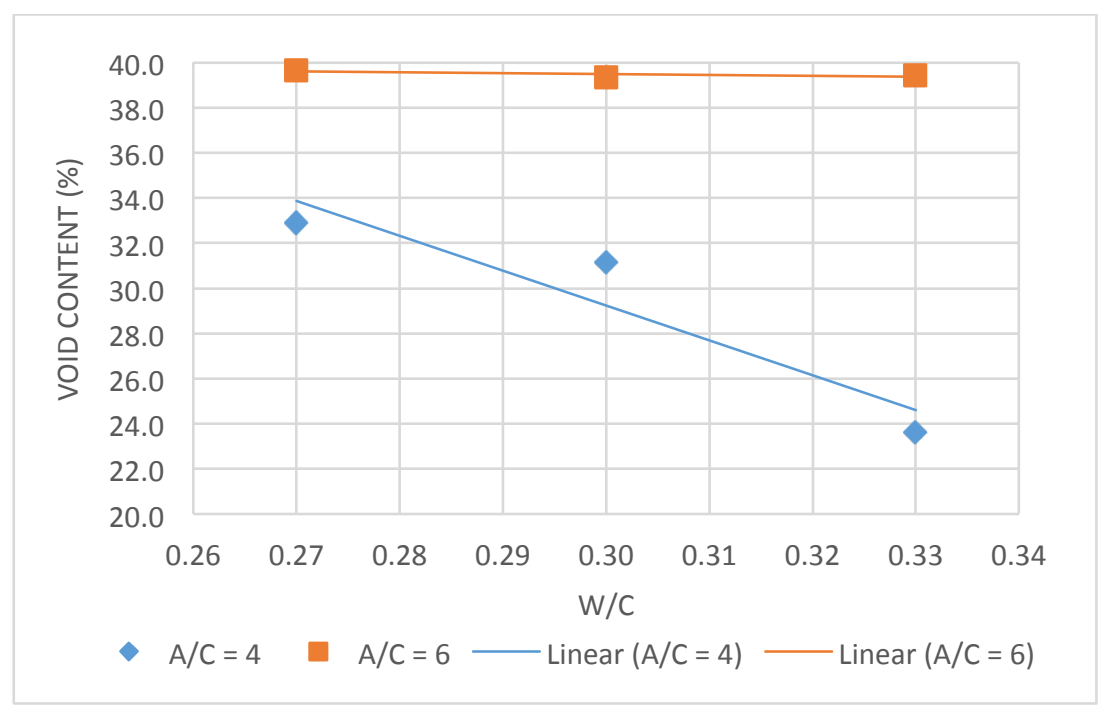

compressivestrength range: $1.9 \mathrm{MPa}-15.4 \mathrm{MPa}$

permeability coefficient range: $2.5 \mathrm{~cm} / \mathrm{sec}-4.7 \mathrm{~cm} / \mathrm{sec}$

Figure2.Relationship between w/c and void content at the age of 28-days. 


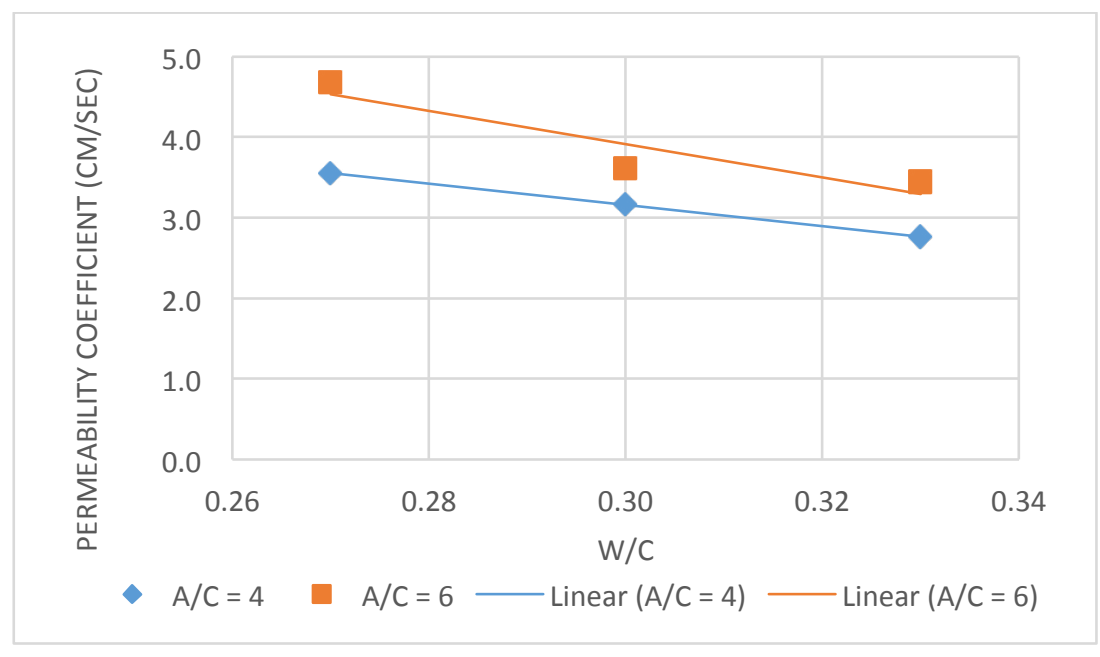

compressivestrength range: $1.9 \mathrm{MPa}-15.4 \mathrm{MPa}$

void content range: $28 \%-40 \%$

Figure3.Relationship between w/c and permeabilityat the age of 28-days.

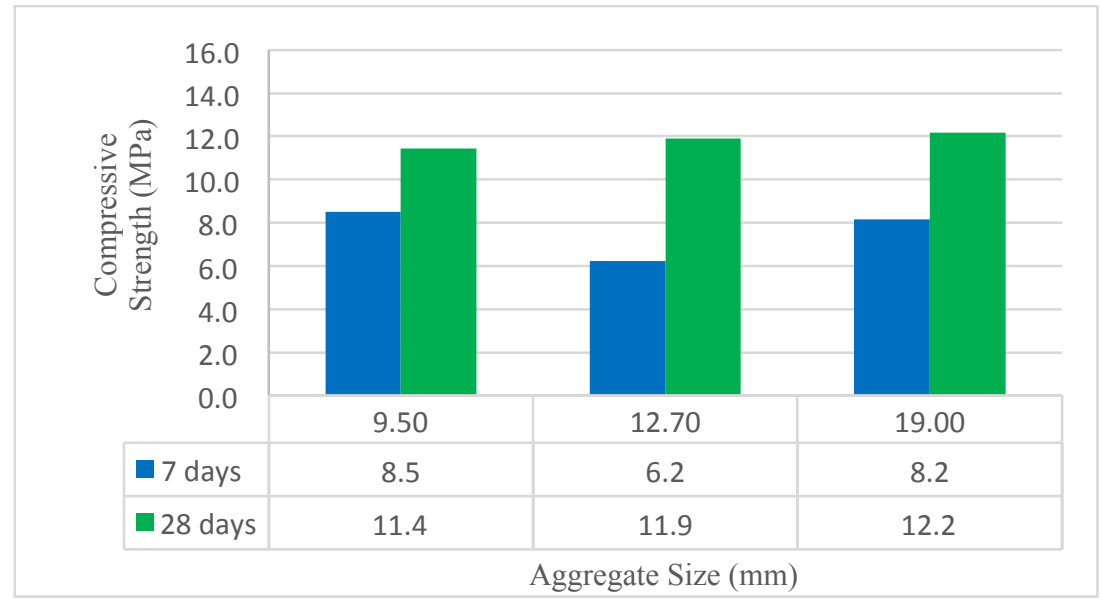

void content range: $27 \%-32 \%$

permeability coefficient range: $1.4 \mathrm{~cm} / \mathrm{sec}-2.6 \mathrm{~cm} / \mathrm{sec}$

Figure 4. Relationship betweenaggregate size and compressive strength.

\begin{tabular}{|rr|r|r|}
\hline & 16.0 & & \\
\hline
\end{tabular}

void content range: $25 \%-32 \%$

permeability coefficient range: $1.0 \mathrm{~cm} / \mathrm{sec}-2.6 \mathrm{~cm} / \mathrm{sec}$ 
Figure 5. Relationship between additive use and compressive strength.

Based on Figure 4 the increase of aggregate size did not give a significant influence against compressive strength value. This situation wasdifferentwhencompared to Crouch [10] whichsaidthatfineraggregate size produced more superior compressive strength value. Turning to Figure $\mathbf{5}$, the sandincreaseuntil $10 \%$ rose the compressive strengthgradually. However, when the sandwasadded more than $10 \%$, the compressive strength value mightdroppedalongwith the growth of time. Because of sand addition, contact area that must becovered by cementpastewouldincrease and the cementpastethatcovering the materialwouldalsodiminish. Moreover, thinnercover by cementpastewouldreduce the bondingstrengthbetweenaggregate and cementpastewhichresultinglower compressive strength. Still on the same figure, the rise of fly-ash as cement replacement until $20 \%$ increased the compressive strength as well. Nevertheless, this condition wasdifferentfromAoki [4] and Muthaiyan [20] statementwhichconcludedthat the compressive strength value wasdeclinedwhenfly-ash content wasincreased. Futhermore, the porousconcrete mixtures withsand and fly-ash inclusion surpassed the minimum compressive strengthrequirements, i.e. $8.0 \mathrm{MPa}$, for base layer onlyin 7-days although the accepted minimum value isin 28-days required by Directorate General of Highways[12].

The followingvoid content and permeability test results are presented on Table 5 and Figure 6 to Figure
9. Table 5exhibitsvarious values of void content and permeabilityat the age of 28-days. Eventhough, twospecimenshadquite far void content value from the targetvoid content, their value stillremainedabove $20 \%$ whichwastargeted in thisstudy. Figure 6 and Figure 7 showthat the increase of aggregate size decreasedvoid content and permeability. Biggeraggregate size causedcementpastethatcovered the contact area becamelessersothatthis excessive cementpastewouldfill the voidinside the mixture. When the void content decreased, the permeabilitywoulddecreased as well. Evenso, this situation wasdifferentwhilecompared to Crouch [10] whichsaidthat the rise of aggregate size producedsimilarvoid content.

Table 5Void content and permeability value of test specimensat the age of 28-days.

\begin{tabular}{|c|c|c|c|}
\hline \multirow{2}{*}{$\begin{array}{c}\text { Target } \\
\text { Void } \\
\begin{array}{c}\text { Content } \\
(\%)\end{array}\end{array}$} & \multicolumn{3}{|c|}{ PorousConcreteSpecimens } \\
\cline { 2 - 4 } & SpecimenNumber & $\begin{array}{c}\text { Void Content } \\
(\%)\end{array}$ & $\begin{array}{c}\text { Permeability } \\
(\mathbf{c m} / \mathbf{s e c})\end{array}$ \\
\hline 29 & $14 \mathrm{D}$ & 29.99 & 2.56 \\
\hline 29 & $16 \mathrm{D}$ & 29.45 & 2.39 \\
\hline 29 & $18 \mathrm{D}$ & 29.21 & 2.37 \\
\hline 29 & 20D & 28.62 & 1.48 \\
\hline 30 & 22D & 26.07 & 1.38 \\
\hline 27 & 24D & 21.91 & 1.02 \\
\hline
\end{tabular}

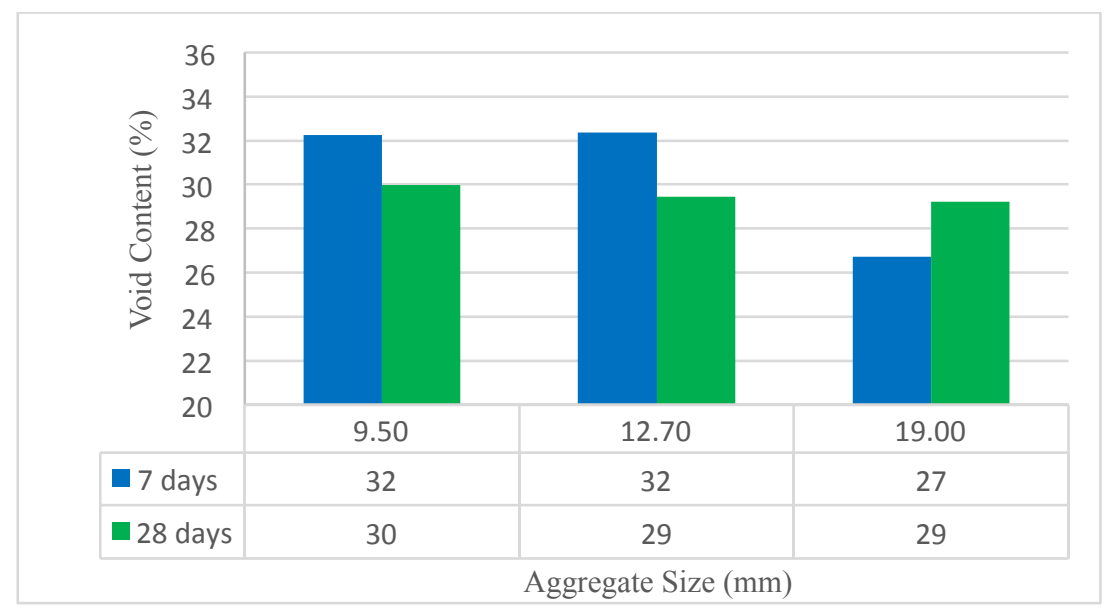

compressivestrength range: $6.2 \mathrm{MPa}-12.2 \mathrm{MPa}$

permeability coefficient range: $1.4 \mathrm{~cm} / \mathrm{sec}-2.6 \mathrm{~cm} / \mathrm{sec}$

Figure 6. Relationship between aggregate size and void content. 


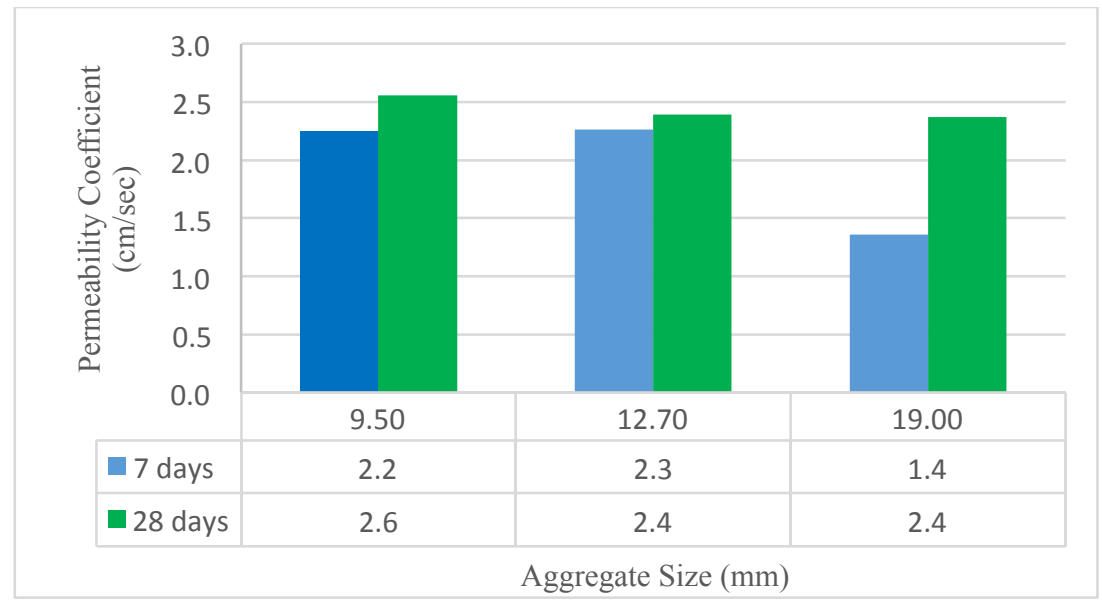

compressivestrength range: $6.2 \mathrm{MPa}-12.2 \mathrm{MPa}$

void content range: $27 \%-32 \%$

Figure 7. Relationship between aggregate size and permeability.

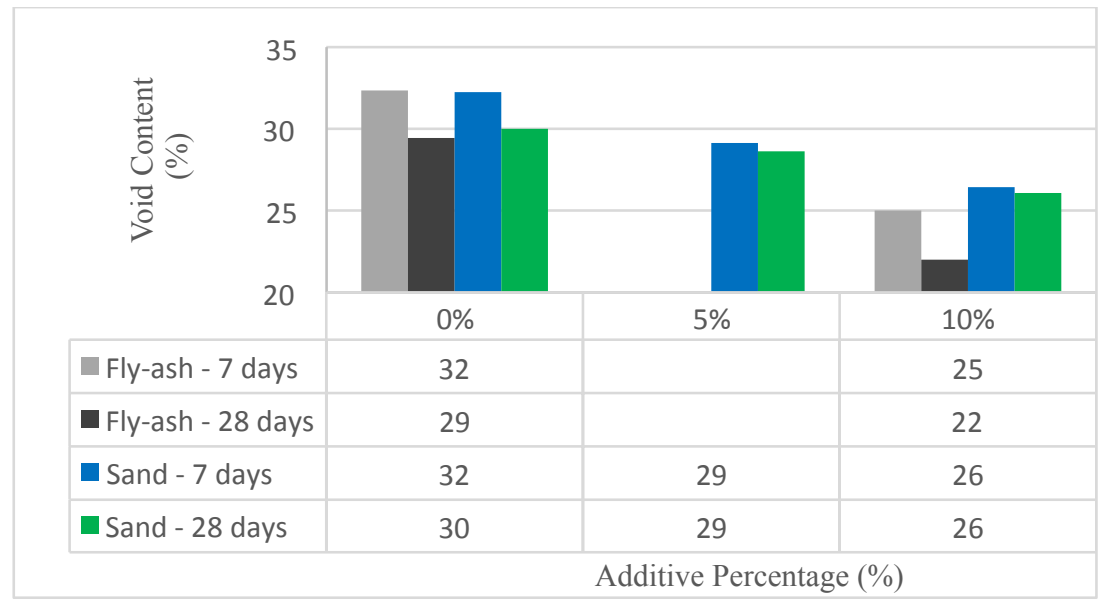

compressivestrength range: $6.2 \mathrm{MPa}-15.2 \mathrm{MPa}$

permeability coefficient range: $1.0 \mathrm{~cm} / \mathrm{sec}-2.6 \mathrm{~cm} / \mathrm{sec}$

Figure 8. Relationship between additive use and void content.

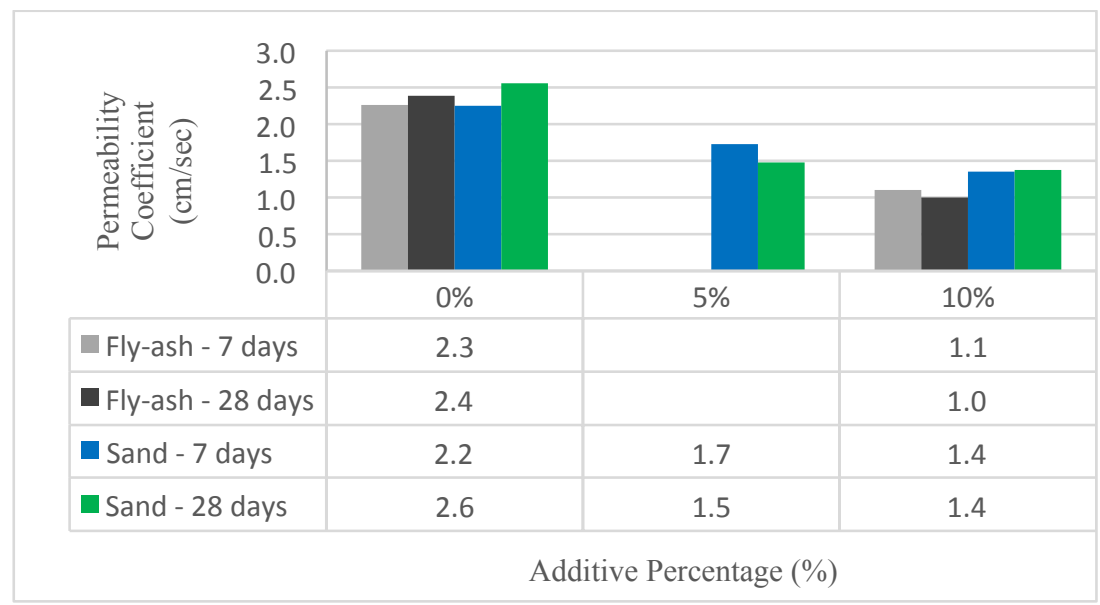

compressivestrength range: $6.2 \mathrm{MPa}-15.2 \mathrm{MPa}$

void content range: $25 \%-32 \%$ 
Figure 9. Relationship between additive use and permeability.

Turning to Figure 8 and Figure 9, sand addition up to $10 \%$ from cement content dropped the void ratio and permeability values (Schaefer [21]). Utilization of flyash up to $20 \%$ also lowered the void ratio and permeability values. This condition walked the same way with Aoki [4] and Muthaiyan [20] which concluded that permeability values tend to drop while fly-ash content was rose. Fly-ash addition lowered void content significantly compared to sand because fly-ash possess typical grain size 100 times smaller and contact area 10 times smaller rather than sand. Additionally, the use of greater aggregate size also produced greater void content. As a result, fly-ash with a smaller grain size had a higher chance to fill the void space rather than sand. All mixtures also produced void content above $20 \%$, wherein this condition could maintain a relatively high level of permeability throughout the service life of pavement (Lim [16]). Futhermore, the porous concrete mixtures with sand and fly-ash inclusion stayed above the minimum permeability requirements, i.e. $0,1 \mathrm{~cm} / \mathrm{sec}$, for base layer in 7-days and 28-days required by Directorate General of Highways [11].

\subsection{Correlation of Basic Parameter}

Correlation test was conducted to observe which variables among the basic parameters were connected and how strong the relationship through the correlation coefficient that was gained from correlation test. Strong relationship was indicated by a high coefficient of correlation value, and vice versa.Several basic properties that were used in this study tried to represent each of the requirements which given by Directorate General of Highways [11] [12], i.e. permeability coefficient to represent run-off performance, compressive strength to represent strength performance. Fresh density and void content were utilized as control variable or independent variable. The results of correlation test are presented on Figure 10 to Figure 14.

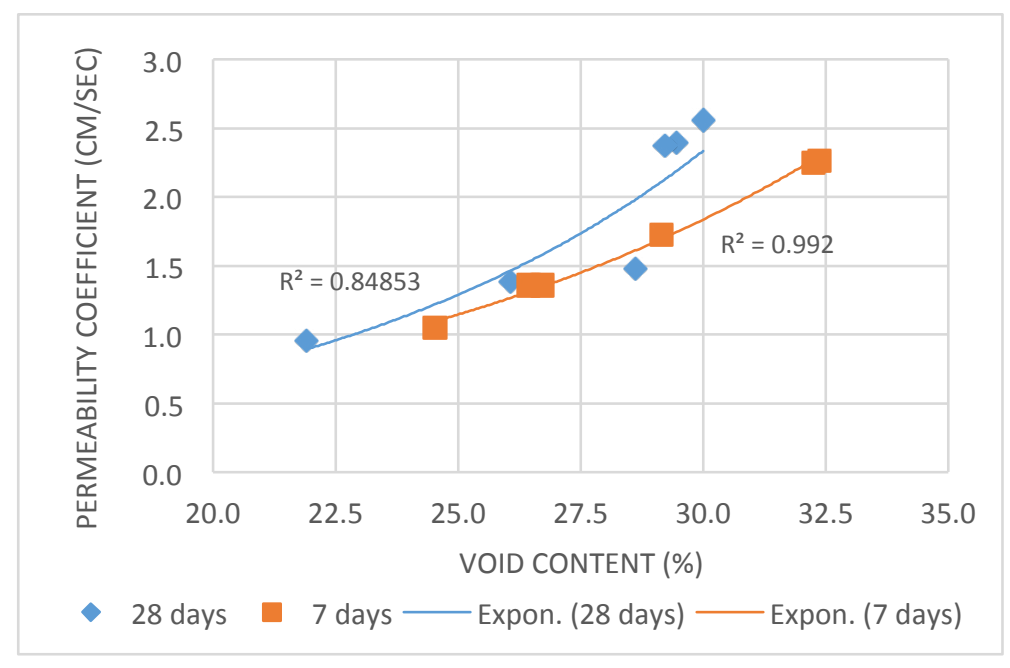

Figure 10. Correlation between porous concrete void content and permeability. 


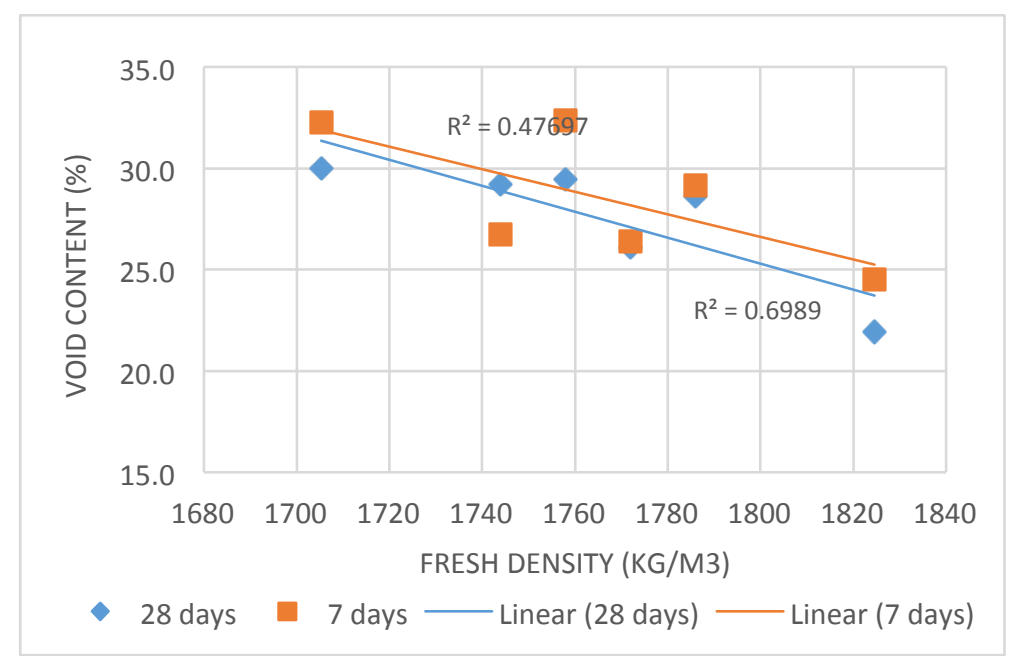

Figure 11. Correlation between porous concrete fresh density and void content.

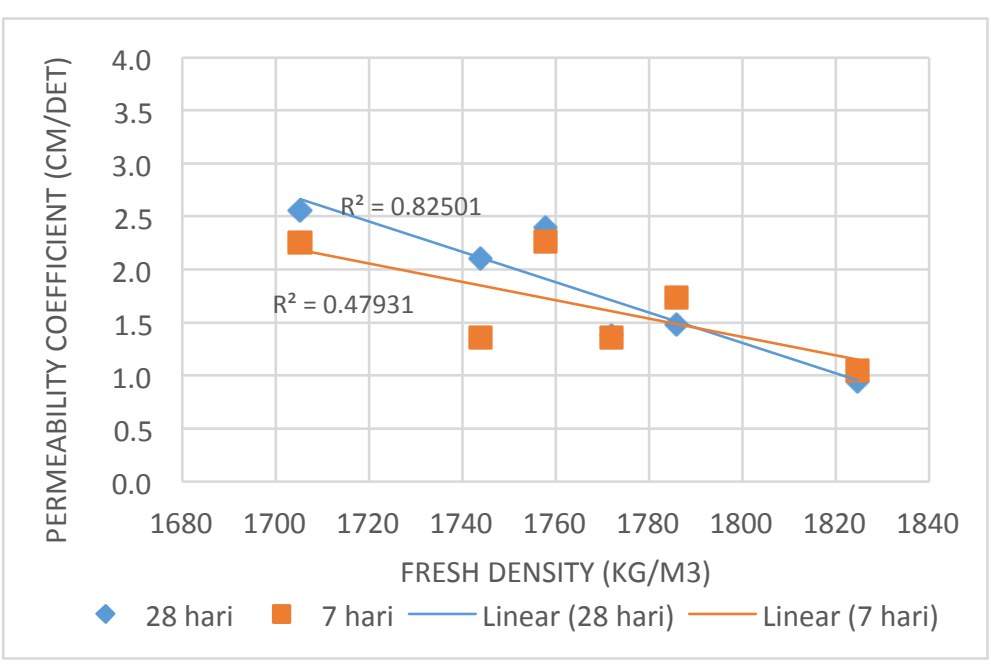

Figure 12. Correlation betweenporousconcretefreshdensity and permeability.

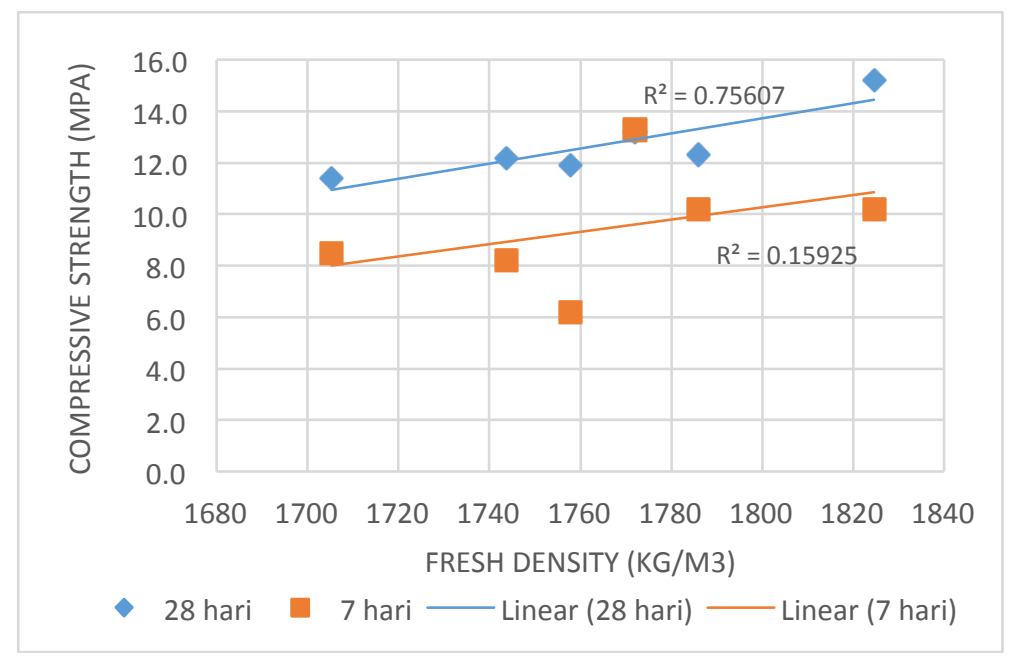

Figure 13. Correlation between porousconcretefreshdensity and compressive strength. 


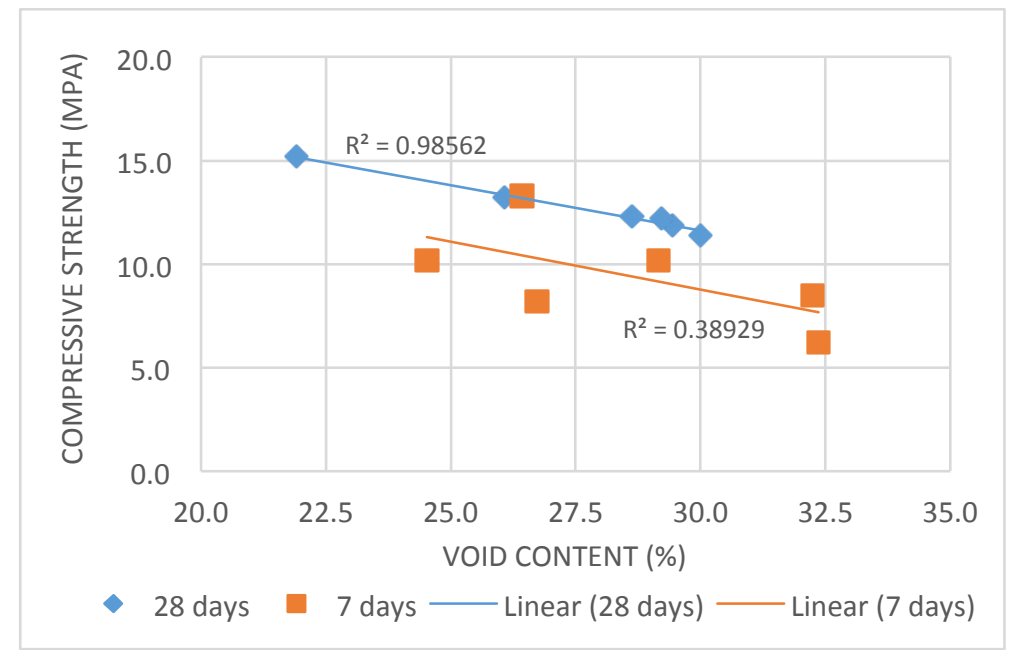

Figure 14. Correlation between porous concrete void content and compressive strength.

Based on correlation test results, the following discussion can be made:

a. Figure 10 illustrated that permeability had a direct and very strong correlation with void content at the age of 7-days and 28-days which was evidenced by a dramatic rise exponentially from permeability value while void content was increased (ACI Committee 522 [1] and Shaefer [21]). Based on this condition, there was fine likelihood to use void content to represent porous concrete permeability behavior.

b. As can be seen on Figure 11 and Figure 12, there were strong negative correlation between fresh density towards void content and permeability at the age of 28-days. Greater fresh density created smaller void and small void would reduce permeability. It was happened because the void inside fresh concrete mixture with a bigger density was filled by cement paste and aggregate. This result strengthened previous test results which were explained by Sonebi [22] and created a fine potency to use the fresh density as a reference to set the desired porous concrete void content on the field.

c. Based on Figure 13 and Figure 14, there were strong correlation between fresh density and void content against compressive strength at the age of 28-days. The increase of fresh density rose the compressive strength significantly. On the contrary, the increase of void content declined the compressive strength gradually. High void content with a good connection resulting weaker aggregate interlocking inside the mixture so that the compressive strength value decreased. On the other hand, compact fresh density with a good aggregate interlocking inside the mixture increased the compressive strength value. These situations showed a close result to the prior results which been obtained by Made [2], Meininger [18] and ACI Committee 522 [1].

d. Looking at Figure 11 - Figure 14, most of age 7daysshowedweak relationship among the parameters. Weak coefficient of correlation values indicated that one parameter had no connection with other parameter and the variability level between two parameters still high. There was lower possibility where if the independent variable increased or decreased, the dependent variable would be increased or decreased as well. This situation might happen because most of pasta semen inside the porous concrete had not fully hydrated yet.

\section{Conclusion}

This paper has presented the procedure and result of laboratory experimental study to obtain basic property criteria for rigid pavement base layer. Those basic parameters were fresh density, compressive strength, void content and permeability. Porous concrete mixture was successfully designed using ACI Committee 522 [1]standard and some references from Meininger's [18] experimental test result. It also surpassed the minimum compressive strength and permeability requirements for base layer which are required by Directorate General of Highways [11] [12]. The compaction method and curing method also gave significant contribution for the porous concrete mix-design. Minimum criteria for mix-design was attained by using water cement ratio 0.30 , aggregate cement ratio 4.0 and varying aggregate size value along with sand addition, fly-ash replacement and chemical additive addition.

It was found that there was very strong correlation between void content and permeability at the age of 7days and 28-days which created fine likelihood to use void content to represent porous concrete permeability behavior. Greater fresh density created smaller void and small void would reduce permeability. High void content with a good connection resulting weaker aggregate interlocking inside the mixture so that the permeability increased and the compressive strength decreased. On the other hand, compact fresh density with a good aggregate interlocking increased the compressive strength value. It was happened because the void inside fresh concrete mixture with a bigger density was filled by cement paste and aggregate. Strong correlation between fresh density towards void 
content and permeability at the age of 28-days opened a fine potency to use the fresh density as a reference to set the desired porous concrete void content on the field. Weak relationship among the parameters at the age of 7-days might happen because most of pasta semen inside the porous concrete had not fully hydrated yet.

\section{References}

1. ACI Committee 522, Report on Pervious Concrete, American Concrete Institute, 7-15 (2010).

2. Amde, A., M., Rogge, S., Development of High Quality Pervious Concrete Specifications for Maryland Conditions, State Highway Adminstration Maryland Department of Transportation, 13-54 (2013).

3. Anderson, Walsh, Oka, Dewoolkar, Limberg, Sevi, Schmeckpeper, Laboratory Performance of Pervious Concrete Subjected to Deicing Salts and Freeze-Thaw, University of Vermont Transportation Research Center, 20-20 (2015).

4. Aoki, Y., Development of Pervious Concrete, M.Eng Thesis, Faculty of Engineering and Technology, University of Technology, Sydney, (2009).

5. ASTM Standards C39/C39M-05, Standard Test Method for Compressive Strength of Cylindrical Concrete Specimens, ASTM International, (2005).

6. ASTM Standards C1688/C1688M-13, Standard Test Method for Density and Void Content of Freshly Mixed Pervious Concrete, ASTM International, (2013).

7. ASTM Standards C1754/C1754M-12, Standard Test Method for Density and Void Content of Hardened Pervious Concrete, ASTM International, (2012).

8. ASTM Standards D5084-03, Standard Test Methods for Measurement of Hydraulic Conductivity of Saturated Porous Materials Using a Flexible Wall Permeameter, ASTM International, (2003).

9. Center of Transportation Infrastructure Research and Development, Pedoman Perencanaan Perkerasan Beton Semen, Department of Regional Settlement and Infrastructure, 7-9, 2020(2003).

10. Crouch, L., K., Pitt, J., Hewitt, R., Aggregate Effects on Pervious Portland Cement Concrete Static Modulus of Elasticity, Journal of Materials in Civil Engineering, 566-566(2007).

11. Directorate General of Highways, Manual of Hydraulic for Road and Bridge Works Hydraulic Design, Department of Public Works,96-96, 99-99 (2005).
12. Directorate General of Highways, Spesifikasi Umum Revisi 3, Ministry of Public Works, 5.665.66 (2010).

13. Federal Highway Administration, Pervious Concrete, The Advanced Concrete Pavement Menttechnology (ACPT) Techbrief, 1-1 (2012).

14. Huang, Y., H., Pavement Analysis and Design, $2^{\text {nd }}$ Edition, Prentice-Hall, Inc., 376-388(2004).

15. Kozeliski, F., A., Permeable Bases Help Solve Pavement Drainage Problems, the Aberdeen Group, 1-2(1992).

16. Lim, E., Fwa, T., F., Tan, K., H., Laboratory Evaluation of Clogging Behaviour of Pervious Concrete Pavements, Journal of the Eastern Asia Society for Transportation StudiesVol. 11, 16111611(2015).

17. McCain, G. N., Dewoolkar, M., M., Porous Concrete Pavements: Mechanical and Hydraulic Properties, TRB 2010 Annual Meeting, 7-18.

18. Meininger, R., C., No-Fines Pervious Concrete for Paving, Concrete InternationalVol. 10 Issue 8, 22-25(1988).

19. Montes, F., Haselbach, L., Measuring Hydraulic Conductivity in Pervious Concrete, Journal of Environmental Engineering and Science, 968-968 (2006).

20. Muthaiyan, U., M., Thirumalai, S., Studies on the Properties of Pervious Flyash-Cement Concrete as a Pavement Material, Cogent Engineering,1516 (2017).

21. Schaefer, V., R., Wang, K., Suleiman, M., T., Kevern, J., T., Mix Design Development for Pervious Concrete in Cold Weather Climates, National Concrete Technology Pavement, 41-41 (2006).

22. Sonebi, M., Bassuoni, M., T., Pervious Concrete: Mix Design, Properties and Applications, Research Gate, 110-113 (2016).

23. Yusak, M., I., M., Jaya, R., P., Hainin, M., R., Ismail, C., R., Ibrahim, M., H., W., Strength of Porous Concrete Pavement at Different Curing Methods, Jurnal Teknologi, 103-103(2015).

24. Zheng, M., Chen, S., Wang, B., Mix Design Method for Permeable Base of Porous Concrete, International Journal Pavement Research TechnologyVol. 5 no.2, China, 102-102(2012). 